Ilmu Pertanian (Agricultural Science)

Vol. 4 No. 2 August, 2019: 65-70

Available online at http://journal.ugm.ac.id/jip

DOI: doi.org/10.22146/ipas.32146

\title{
Effect of Salt Pretreatment on the Growth and Yield of Oryza sativa L. (cv. Dendang) under Saline Condition
}

\author{
Nindya Arini, Budiastuti Kurniasih* and Sriyanto Waluyo \\ Department of Agronomy, Faculty of Agriculture, Universitas Gadjah Mada \\ Jln. Flora no. 1, Bulaksumur, Sleman, Yogyakarta 55281, Indonesia \\ *Corresponding author: tuti_b@ugm.ac.id
}

Received: 09 $9^{\text {th }}$ January 2018; Revised: $10^{\text {th }}$ May 2019; Accepted: $29^{\text {th }}$ July 2019

\begin{abstract}
Productivity of rice as staple food of Indonesia needs to be improved. One of the efforts is by utilizing saline area for agricultural land. Salinity can be a serious problem leading to a decrease in crop productivity. Plant adaptation under salinity is an alternative to lower the risk, which can be improved by seedling pretreatment. The experiment was conducted in Baros, Kretek, Bantul, Yogyakarta. The objective of this research was to determine the growth and yield response of rice cv. Dendang to the salt pretreatment at early stage. The experiment was arranged in completely randomized design. The treatments used were salt pretreatment and without salt pretreatment. The salt pretreatment increased $\mathrm{K}+$ concentration, total dry matter, plant height and number of tillers. However, it decreased proline and $\mathrm{Na}+$ concentration of leaf. There was no significant difference on the yield and yield component. Increasing EC values up to $8.35 \mathrm{dSm}^{-1}$ at generative phase reduced the rice ability to cope this level of salinity despite the application of salt pretreatment. The benefit of salt pretreatment was exhibited on rice grown under EC value $5 \mathrm{dSm}^{-1}$.
\end{abstract}

Keywords: Rice, salinity, salt pretreatment.

\section{INTRODUCTION}

Rice is one of the most important crops and it is the primary staple food in Indonesia. Paddy field area is decreasing along with the increase in human population. Therefore, it is necessary to enhance the growth and yield of rice to balance the population growth. One of the efforts is to improve productivity of rice in marginal land. Indonesia has 40-43 million ha marginal field of which around 13.2 million ha is saline area (Suriadikarta and Sutriadi, 2007)

Salinity itself becomes a serious problem in rice cultivation. Chinnusamy et al. (2005) state that saline soils and saline water are major constraints affecting the production and quality of rice. Rice is considered to be moderately sensitive to salinity (Maas and Hoffman, 1977). High concentration of salt in soil can significantly decrease the productivity of rice. Zeng and Shanon (2000) reported that rice yield decreased about $50 \%$ due to salinity limiting the rice growth and development.

An attempt is needed to reduce the impact of salinity on crop performance and yield. One of them is by inducing the salinity tolerance. Pre-planting treatment is one component of the cultivation technology in the saline field by increasing the germination rate and performance or vigorous index in a wide spectrum, which is also effective under stress conditions (Liming et al., 1992) such as water and saline stress. This treatment is an easy, low cost, and low risk technique which can be used to overcome the salinity problem (Nawaz et al., 2013). Suwignyo et al. (2011) stated that the pre-planting treatment could increase plant tolerance to salinity.

Seed pretreatment stimulates many of the metabolic processes (physiological and chemical) involved in the early phases of germination. The seedling treated with salt pretreatment increases the germination rate and produces more vigorous and better seedling performance under saline conditions (Cramer, 2002). Previous study in Aeluropus macrostachys plant have shown that the use of salt pretreatment has a relatively tolerance against salinity. Sivritepe et al. (2003) observed that EC values $5 \mathrm{dSm}^{-1}$ as pretreatment on melon crop induced higher adaptation capacity of salinity. The other study on maize (Gebreegziabher 
and Qufa, 2017) showed that EC values 5 and 7 $\mathrm{dSm}^{-1}$ stimulated the physiological activities of maize seeds, which resulted in rapid and uniform seed germination. Cultivar Dendang is one of the cultivars that are able to adapt to the saline soil. The potential yield of cv. Dendang is 5 ton.ha ${ }^{-1}$. This research aimed to study the impact of salt pretreatment on the growth and yield of rice cv. Dendang .

\section{MATERIALS AND METHODS}

This research was conducted from October 2016 to February 2017 in Baros, Kretek, Bantul, Yogyakarta. The primary materials used in this research were the rice seeds cv. Dendang, manure and NPK fertilizer $\left(15 \% \mathrm{~N}, 15 \% \mathrm{P}_{2} \mathrm{O}_{5}, 15 \% \mathrm{~K}_{2} \mathrm{O}\right.$, and $\left.10 \% \mathrm{~S}\right)$, groundwater (EC 4-5 dSm$\left.{ }^{-1}\right), \mathrm{NaNO}_{3}$, ninhydrin acid, $1 \%$ sulphanilamide, HCL $3 \mathrm{~N}, 0.02 \%$ Naphtylefilendiamide, $3 \%$ sulpho-salicylic acid, $\mathrm{HNO}_{3}$, toluene, and distilled water. The laboratory tools used were spectrophotometer, LICOR LI-6400, EC meter, micro pipette, digital scales, flame photometer, water pump, hose, hand counter, roll meter, oven, plants scissors, nets, stationery, cultivation tools, paper bags, plastic bags and raffia straps.

The experiment was arranged in a Random Complete Block Design (RCBD) with one factor. The factor consisted of two levels, salt pretreatment (T1) and without salt pretreatment (T2). The salt pretreatment was applied at the beginning of radicle and coleoptile emergence until the seedling were transplanted to the field. EC values of salt pretreatment at seedling stage was $5 \mathrm{dSm}^{-1}$. The seedlings were transplanted to the field at 28 days after germination. The size of the experimental unit used was $3 \times 3 \mathrm{~m}$ each plot. Saline stress condition in the field was set using river water as the irrigation source with EC values of 4-7 $\mathrm{dSm}^{-1}$. The EC values of irrigation water was checked before it was pumped into the land. It was applied for 2-3 a days until flowering stage. The data observed were leaf $\mathrm{Na}^{+}$and $\mathrm{K}^{+}$ concentration (Munns et al., 2010), proline concentration (Bates et al., 1974), nitrate reductase activity (Hari et al., 1982), photosynthesis rate (Sunghening, 2015), plant height, number of tiller, total dry weight, number of grain per panicles, percentage of filled grain per panicles, panicle length, grain weight per plant, number of grain per plant and dry grain yield. All the data observed were analyzed by using t-test.

\section{RESULTS AND DISCUSSION}

The electrical conductivity (EC) of river water used for irrigation fluctuated from the beginning to the end of the experiment. It was due to the low and high rain fall. The highest EC value $\left(8.35 \mathrm{dSm}^{-1}\right)$ was observed at 10 weeks after planting (WAP). The high EC value was presumably affected by the accumulation from previous irrigation.

\section{$\mathrm{Na}^{+}$and $\mathrm{K}^{+}$Concentration of cv. Dendang}

The responses of plant to salinity were first determined by measuring the $\mathrm{Na}^{+}$and $\mathrm{K}^{+}$concentration in the leaves. Table 1 showed that there was significant difference in $\mathrm{Na}^{+}$concentration at 25 days after planting (DAP), in which seedlings without salt pretreatment had a higher $\mathrm{Na}^{+}$concentration than seedlings with salt pretreatment. Plants accumulate more $\mathrm{Na}^{+}$in leaf tissue than in the other organs. The high salinity in the root area causes the plant to accumulate more salt.

In this study, plant with salt pretreatment had a lower $\mathrm{Na}^{+}$concentration than plant without salt pretreatment at 25 days after planting. Meanwhile, $\mathrm{K}^{+}$concentration was higher in seedlings salt pretreatment compared to those without salt pretreatment. Under salinity stress conditions, the presence of $\mathrm{Na}^{+}$concentration is inversely proportional to $\mathrm{K}^{+}$concentration. Increased absorption of $\mathrm{Na}^{+}$ ions results in the accumulation of high ions in plant tissues (Staples et al., 1984), resulting in obstacles in the absorption of $\mathrm{K}^{+}, \mathrm{Ca}^{2+}$ and $\mathrm{NO}^{3-}$ (Maas, 1997). Greenway and Munns (1980) reported that the plants that contain low concentration of $\mathrm{Na}^{+}$in the roots and other organs under salt stress are suspected to have salt tolerance. However, there was no any

Table 1. $\mathrm{Na}^{+}$and $\mathrm{K}^{+}$concentration of leaf at $25 \mathrm{DAP}, 54 \mathrm{DAP}$, and at harvest time

\begin{tabular}{lcccccc}
\hline \multirow{2}{*}{ Treatment } & \multicolumn{3}{c}{$\mathrm{Na}^{+}\left(\mathrm{mmol} . \mathrm{g}^{-1} \mathrm{FW}\right)$} & \multicolumn{3}{c}{$\mathrm{K}^{+}\left(\mathrm{mmol} . \mathrm{g}^{-1} \mathrm{FW}\right)$} \\
\cline { 2 - 7 } & $25 \mathrm{DAP}$ & 54 DAP & harvest & 25 DAP & 54 DAP & Harvest \\
\hline Salt pretreatment (T1) & 1.13 & 1.74 & 109 & 62.4 & 60.2 & 42.1 \\
Non Salt pretreatment (T2) & $2.24\left(^{*}\right)$ & 2.47 & 113 & $49.9\left(^{*}\right)$ & 60.7 & 52.8 \\
\hline
\end{tabular}

Remark: Fresh weight (FW); Days after planting (DAP); (*) indicate statistically significant differences based on the t-test at $\alpha=5 \%$. 
Table 2. Proline and nitrate reductase activity of leaf at 25 and 54 days after planting (DAP)

\begin{tabular}{lcccc}
\hline \multirow{2}{*}{ Treatment } & \multicolumn{2}{c}{ Prolin $(\mathrm{ppm})$} & \multicolumn{2}{c}{ NRA $\left(\mu \mathrm{mol} \mathrm{NO} \mathrm{NO}^{2-} \cdot \mathrm{g}^{-1} \cdot\right.$ hour } \\
\cline { 2 - 5 } & $25 \mathrm{DAP}$ & $54 \mathrm{DAP}$ & $25 \mathrm{DAP}$ & 54 DAP \\
\hline Salt pretreatment (T1) & 13.8 & 7.0 & 5.4 & 3.8 \\
Non Salt pretreatment (T2) & 12.8 & $7.2(*)$ & 11.8 & 5.6 \\
\hline
\end{tabular}

Remark: $(*)$ indicate statistically significant differences based on the t-test at $\alpha=5 \%$.

Table 3. Photosynthesis rate at 54 days after planting

\begin{tabular}{lc}
\hline Treatment & Photosynthesis rate $\left(\mu \mathrm{mol} \mathrm{CO} 2 . \mathrm{m}^{-2} \cdot \mathrm{s}^{-1}\right)$ \\
\hline Salt pretreatment (T1) & 0.044 \\
Non Salt pretreatment (T2) & 0.039 \\
\hline
\end{tabular}

Remark: $\left({ }^{*}\right)$ indicate statistically significant differences based on the t-test at $\alpha=5 \%$.

significant difference in $\mathrm{Na}+$ concentration between treatments at 54 DAP and harvest time. There was also no significant difference in $\mathrm{K}^{+}$concentration between the treatments at 54 days after planting and harvest time.

\section{Proline and Nitrate Reductase Activity Content}

Accumulation of solutes especially proline is a common observation under the saline stress condition. Proline accumulation in plants under salt stress is a primary defense response to maintain the osmotic pressure in a cell (Turan et al., 2009). Leaf is a part of plant that contains highest accumulation of proline. The data (Table 2) showed that proline concentration in leaf without salt pretreatment was significantly $(\mathrm{p} \leq 0.05)$ higher than proline concentration in leaf with salt pretreatment at 54 days after planting. The increase in $\mathrm{Na}^{+}$concentration causes the plant with salt pretreatment to have a higher salt concentration. Plants have developed an efficient method to keep the ion concentration in the cytoplasm in a balance. In these plants, osmotic balance is generally achieved via extensive accumulation of organic solutes and/or inorganic ions (Gupta and Huang, 2014). Proline and glycine betaine were reported as the best-known compatible solutes that increase greatly under salt stress (Carillo et al., 2011). Plants without salt pretreatment accumulated more compatible solutes in response to the presence of excess $\mathrm{Na}^{+}$so that the concentration of proline was high. There was no significantly difference in nitrate reductase activity between salt pretreatment and without salt pretreatment.

\section{Photosynthesis rate}

The result of photosynthesis rate under saline condition at 54 days after planting was not significantly affected by salt pretreatment. It may happen because the high salt stress just occurred at the generative phase, thus, the plant was quite strong enough to resist the salt. In this study, the high salt stress at generative phase was caused by the decrease in rainfall so that the river water as saline irrigation source had a high concentration of salt.

\section{Plant Height, number of tillers, and total dry matter}

Based on the $t$ test, the plant height was not significantly $(\mathrm{p} \leq 0.05)$ different between the plants with salt pretreatment and without salt pretreatment. However, according to the graph (Figure 1), plants

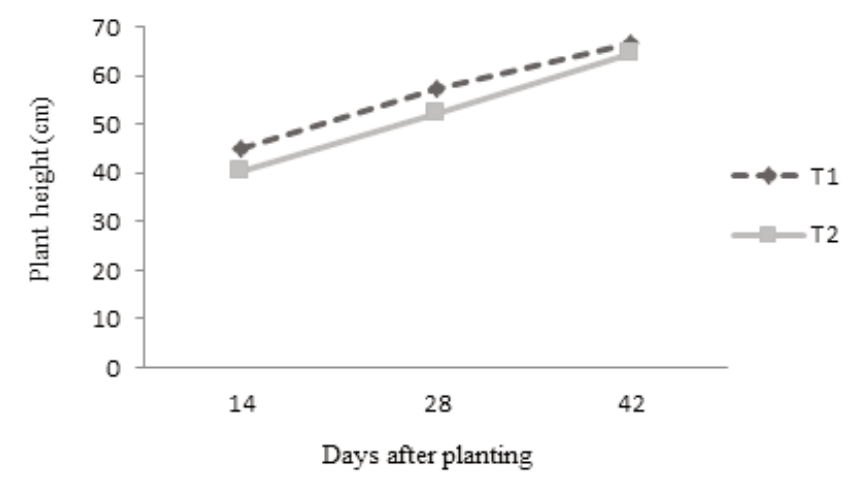

Figure 1. Plant height of rice cv. Dendang with salt pretreatment (T1) and without salt pretreatment (T2) 
with salt pretreatment produced a higher plant height than without salt pretreatment until 42 DAP. A good impact of salt pretreatment on plant height had been reported by Sivritrepe et al. (2003) in which melon seedlings treated with salt pretreatment under saline condition (EC values $5 \mathrm{dSm}^{-1}$ ) had a higher plant height than those without salt pretreatment.

According to Table 4, the effect of salt pretreatment on the number of tillers was not significant $(p<0.005)$ although Figure 2 showed a trend that number of tillers of plants with salt pretreatment was higher than those without salt pretreatment along with the time. The number of tillers that tended to be high in this phase was thought to be associated with good performance of plants with salt pretreatment (data not showed). Krishnasamy and Seshu (1989) informed that yield and number of tillers per plant showed positive association with the good performance at seedling stage. The performance of seedlings affected the condition of the plant after being planted in the field.

According to the Table 4, there was no significant difference between salt pretreatment and without pretreatment in total dry matter. Total crop dry matter is the spatial and temporal integration of all plants processes. From the data of EC values during the experiment, the highest soil EC values was observed at generative phase (49-63 DAP), showing a range of $6-9 \mathrm{dSm}^{-1}$. However, plant is more tolerant to salinity at the generative phase.

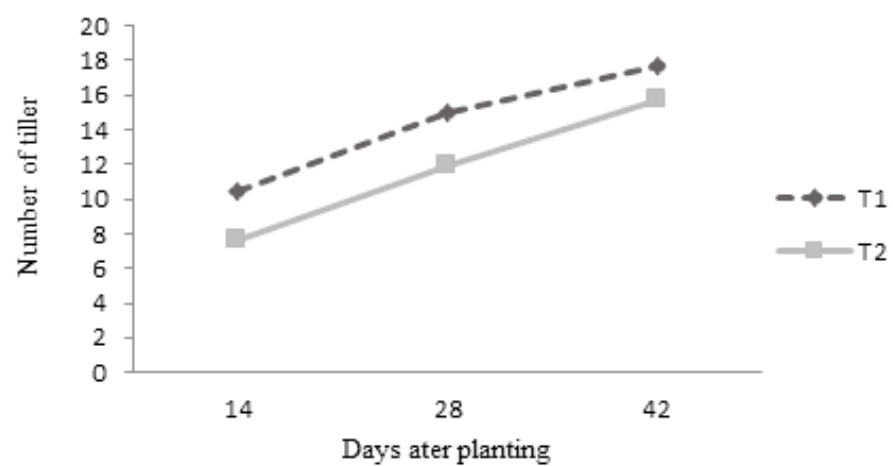

Figure 2. Number of tillers of rice cv. Dendang with salt pretreatment (T1) and without salt pretreatment (T2)

Table 4. Plant height and number of tiller at 42 days after planting, total dry matter at 108 days after planting

\begin{tabular}{lccc}
\hline Treatment & Plant height $(\mathrm{cm})$ & Number of tiller & Total dry matter $(\mathrm{g})$ \\
\hline Salt pretreatment (T1) & 66.5 & 17.6 & 53.6 \\
Non Salt pretreatment (T2) & 64.3 & 15.6 & 42.6 \\
\hline
\end{tabular}

Remark: $(*)$ indicate statistically significant differences based on the t-test at $\alpha=5 \%$.

Table 5. Number of grain per panicles, percentage of filled grain per plant and panicle length

\begin{tabular}{lccc}
\hline Treatment & $\begin{array}{c}\text { Number of grains } \\
\text { per panicles }\end{array}$ & $\begin{array}{c}\text { Percentage of filled } \\
\text { grain per plant }(\%)\end{array}$ & $\begin{array}{c}\text { Panicle length } \\
(\mathrm{cm})\end{array}$ \\
\hline Salt pretreatment (T1) & 103 & 79.1 & 22.4 \\
Non Salt pretreatment (T2) & 93 & 76.8 & 22.5 \\
\hline
\end{tabular}

Remark: $(*)$ indicate statistically significant differences based on the t-test at $\alpha=5 \%$.

Table 6. Grain weight/plant, number of grain per plant and dry grain yield

\begin{tabular}{lccc}
\hline Treatment & $\begin{array}{c}\text { Grain weight } \\
\text { per plant }(\mathrm{g})\end{array}$ & $\begin{array}{c}\text { Number of grain } \\
\text { per plant }\end{array}$ & $\begin{array}{c}\text { Dry grain yield } \\
\text { (ton. ha } \text { h }^{-1}\end{array}$ \\
\hline Salt pretreatment (T1) & 17.4 & 986 & 4.35 \\
Non Salt pretreatment (T2) & 15.9 & 969 & 3.97 \\
\hline
\end{tabular}

Remark: $\left(^{*}\right)$ indicate statistically significant differences based on the t-test at $\alpha=5 \%$. 


\section{Grain Yield}

Although previous data showed that salt pretreatment gave a higher plant height, higher number of tillers, higher $\mathrm{K}^{+}$concentration, lower $\mathrm{Na}^{+}$concentration and lower proline concentration at vegetative phase, Table 5 and 6 showed that there was no significant effect ( $p>0.005)$ of salt pretreatment on the yield components. The electrical conductivity (EC) of irrigation water used from the beginning to the end of the experiment was fluctuating. The highest EC value $\left(8.35 \mathrm{dSm}^{-1}\right)$ was observed at 74 days after planting when the plant was at the generative phase. It was presumably due to the low and high rainfall. The high EC value was suspected to be affected by the accumulation from previous irrigation and low rainfall. The rapid increase in EC values at the generative phase made the effect of salt pretreatment not as significant as the effect at vegetative phase.

Table 6 showed that there was no significant effect of salt pretreatment on the grain weight per plant, number of grains per plant and dry grain yield. Binang et al. (2012) informed that the effect of salt pretreatment on yield would depend on the type of stresses that seedling was exposed to. Cayuela et al. (2001) also reported that the stress level used for seedling pretreatment would affect the salt tolerance, in which if salt concentration used in the pretreatment is under the stress threshold, the plants are unable to increase their salt tolerance levels.

\section{CONCLUSIONS}

It was apparent that at the vegetative phase, salt pretreatment to the seedlings increased $\mathrm{K}^{+}$ concentration, plant height and number of tillers. However, it decreased $\mathrm{Na}^{+}$and proline concentrations. Salt pretreatment did not give effect when EC value reached $8.35 \mathrm{dSm}^{-1}$. It is proved that salt pretreatment with EC values of $5 \mathrm{dSm}^{-1}$ can be used as a way to enhance salinity tolerance when rice is grown under EC of $5 \mathrm{dSm}^{-1}$.

\section{ACKNOWLEDGEMENT}

The authors would like to express deep gratitude to the Ministry of Research Technology and Higher Education Republic of Indonesia (KEMENRISTEK DIKTI) for the funding provided for this research.

\section{REFERENCES}

Askari, N. H. 2013. The effects of seed priming techniques in improving germination and early seedling growth of Aeluropus macrostachys. Int. J. of Advanced Biological and Biomedical Research, 1: 86-95.

Bates, L.S., R.P. Waldren and L.D. Teare. 1973. Rapid determination of free proline for waterstress studies. J. Plant and Soil, 39: 205-207.

Binang, W.B., J.O. Shiyam and J.D. Ntia. 2012. Effect of seed priming method on agronomic performance and cost effectiveness of rainfed, dry-seeded NERICA rice. $J$. Research of Seed Science, 4: 136-143.

Carillo, P., M.G. Annunziata, G. Pontecorvo, A. Fuggi and P. Woodrow. 2011. Salinity stress and salt tolerance, p. 21-38. In: Shanker A., and venkateswaralu B. (eds). Abiotic stress in plants-mechanism and adaptations, Croatia.

Cayuela, E., M.T. Estañ, M. Parra, M. Caro and M.C. Bolarin. 2001. NaCl pre-treatment at the seedling stage enhances fruit yield of tomato plants irrigated with salt water. J. Plant and Soil, 2: 231-238.

Chinnusamy, V, A. Jagendorf and J.K. Zhu. 2005. Understanding and improving salt tolerance in plants. J. Crop Science, 45: 437-448.

Cramer, G.R. 2002. Sodium-calcium interactions under salinity stress, p. 205-227. In : Läuchli A., Lüttge U. (eds). Salinity: EnvironmentPlants-Molecules. Springer, Dordrecht.

Gebreegziabher, B.G. and C.A. Qufa. 2017. Plant physiological stimulation by seeds salt priming in maize (Zea mays): Prospect for salt tolerance. African Journal of Biotechnology, 5: 209-223.

Greenway, H. and R. Munns. 1980.Mechanisms of salt tolerance in nonhalophytes. Annual Review of Plant Physiology, 1: 149-190.

Gupta, B. and B. Huang. 2014. Mechanism of salinity tolerance in plants: physiological, biochemical, and molecular characterization. International Journal of Genomics, 3: 1-18.

Krishnasamy, V. and D.V. Seshu. 1989. Seed germination rate and associated characters in rice. J. Crop Science, 4: 904-908.

Liming, S., D.M. Orcutt and J.G. Foster. 1992. Influence of polyethylene glycol and aeration method during imbibition on germination and subsequent seedling growth of flatpea (Lathy russylvestris). J. Seed Science and Technology, 3: 349-357. 
Maas, E.V. and G.J. Hoffman. 1977. Crop salt tolerance current assessment. Journal of the Irrigation and Drainage Division, 2: 115-134.

Munns, R., P.A. Wallace, N.L. Teakle and T.D. Colmer. 2010. Measuring Soluble Ion Concentrations $\left(\mathrm{Na}^{+}, \mathrm{K}^{+}, \mathrm{Cl}^{-}\right)$in Salt-Treated Plants, p. 371-282. In: Sunkar R. (eds) Plant Stress Tolerance. Methods in Molecular Biology (Methods and Protocols), Humana Press.

Nawaz, J., M. Hussain, A. Jabbar, G.A. Nadeem, M. Sajid, M.U. Subtain and I. Shabbir. 2013. Seed priming a technique. International Journal of Agriculture and Crop Sciences, 20: 1373.

Sivritepe, N., H.O. Sivritepe and A. Eris. 2003. The effects of $\mathrm{NaCl}$ priming on salt tolerance in melon seedlings grown under saline conditions. J. Scientia Horticulturae, 3: 229-237.

Sunghening, W. 2015. Characteristic physiology and yield mung bean (Vigna radiata, L.) at different shade level at Bugel coastal land Kulon Progo. (Thesis). Universitas Gadjah Mada.
Suriadikarta, D.A. and M.T Sutriadi, M.T. 2007. Jenis jenis lahan berpotensi untuk pengembangan pertanian di lahan rawa. Jurnal Litbang Pertanian, 3: 115-122.

Suwignyo, R.A., Renih and Mardiyanto. 2011. Pengaruh perlakuan salinitas awal rendah terhadap pertumbuhan dan toleransi salinitas tanaman jagung. Jurnal Agrivigor, 10: 13-19.

Turan, M.A., A.H.A. Elkarim, N. Taban and S. Taban. 2009. Effect of salt stress on growth, stomatal resistance, proline and chlorophyll concentrations on maize plant. African Journal of Agricultural Research, 9: 893-897.

Zeng, L. and M.C. Shannon. 2000. Salinity effects on seedling growth and yield components of rice. J. Crop Science, 40: 996-1003. 